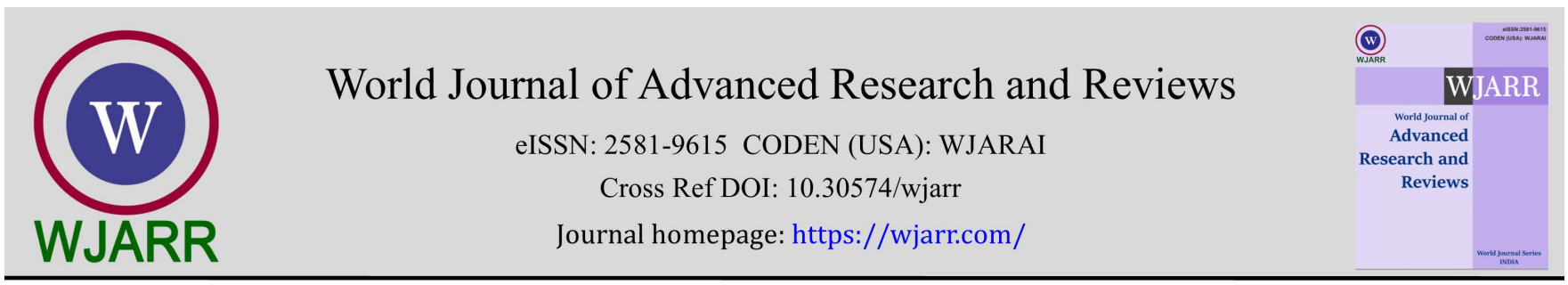

(RESEARCH ARTICLE)

\title{
Biochemical parameters of mild, moderate \& severe COVID-19 patients
}

\author{
Khushbun Nahar Layla ${ }^{1,}{ }^{*}$, Shahanara Yeasmin ${ }^{2}$, Sharif Ahmed Khan ${ }^{3}$, Masba Uddin Chowdhury ${ }^{4}$, Afrina \\ Binte Azad ${ }^{5}$ and Farzana Yeasmin Mukta ${ }^{6}$ \\ ${ }^{1}$ Department of Physiology, Ibrahim Medical College, Dhaka, Bangladesh. \\ 2 Department of Physiology, Dhaka Medical College, Dhaka, Bangladesh. \\ ${ }^{3}$ Department of Gastroenterology and Medicine, United Hospital Ltd, Dhaka, Bangladesh. \\ ${ }^{4}$ Department of Haematology. Evercare Hospital Ltd. Dhaka, Bangladesh. \\ ${ }^{5}$ Department of Physiotherapy, National Institute of Traumatology and Orthopaedic Rehabilitation, Dhaka, Bangladesh. \\ ${ }^{6}$ Department of Cardiology, Kurmitola General Hospital, Dhaka, Bangladesh.
}

World Journal of Advanced Research and Reviews, 2021, 11(02), 031-039

Publication history: Received on 25 June 2021; revised on 30 July 2021; accepted on 02 August 2021

Article DOI: https://doi.org/10.30574/wjarr.2021.11.2.0348

\begin{abstract}
Background and objectives: Coronavirus disease 2019 (COVID-19) is affecting millions of people world-wide. It is caused by the severe acute respiratory syndrome corona virus 2(SARS-CoV-2). The laboratory findings are very important to assess the progress of the disease. The present study is aimed to discuss the biochemical parameters among mild, moderate and severe COVID-19 patients.
\end{abstract}

Materials and methods: A cross sectional study were conducted in the Department of Physiology, Dhaka Medical College, Dhaka from January 2020 to December 2020. After obtaining ethical clearance, a total of 100 real timepolymerase chain reaction (RT-PCR) COVID-19 positive patients were selected from Dhaka Medical College Hospital. With all aseptic precautions, $10 \mathrm{ml}$ of venous blood was collected from ante-cubital vein. D-dimer, prothrombin time, Creactive protein (CRP), lactate dehydrogenase ( $\mathrm{LDH}$ ), serum ferritin, random blood glucose (RBG), serum creatinine, serum glutamic-pyruvic-transaminase (SGPT) and serum albumin measured in the Department of Laboratory Medicine, Dhaka Medical College Hospital, Dhaka. CRP was measured by Immunoturbidimetric method, serum ferritin was estimated by Chemiluminescent microparticle immunoassay. STA-neoplastine CI plus used with STA-R analyzer was used for determination of prothrombin time. D-dimer was estimated by Immunofluorescence Assay method. Serum LDH is measured by Dimention clinical chemistry system, serum albumin is measured by bromocresol purple dye binding method, serum creatinine is measured by Jaffe alkaline picrate method and serum SGPT is measured by colourmetric (IFCC 1980) method and RBG is measured by enzymatic colorimetric method (GOD-PAP). Data were recorded in a pre-designed structured data collection form. For statistical analysis, ANOVA followed by Bonferroni test, Chi square test, Spearman's rho correlation coefficient test was performed as applicable using SPSS for windows version 25.0.

Results: By analyzing biochemical parameters of mild, moderate and severe RT-PCR positive 100 COVID-19 patients revealed evaluation of biochemical parameters shows severity of the disease was significantly associated with CRP, SGPT, S. Creatinine, LDH, Ferritin, D-dimer \& Prothrombin time. No significant association was found with RBG \& S. Albumin. Bonferroni correction following ANOVA was performed to compare between each group. Spearman's correlation reveals statistically significant strong positive correlation with CRP, Ferritin \& D-dimer, moderate positive correlation with S. Creatinine, LDH and mild positive correlation with SGPT \& Prothrombin time.

\footnotetext{
* Corresponding author: Khushbun Nahar Layla

Department of Physiology, Ibrahim Medical College, Dhaka, Bangladesh.

Copyright $(2021$ Author(s) retain the copyright of this article. This article is published under the terms of the Creative Commons Attribution Liscense 4.0.
} 
Conclusion: This study showed D-dimer, prothrombin time, CRP, LDH, ferritin, serum creatinine and SGPT are significantly associated with the severity of the illness that is higher in severe group in comparison to mild and moderate groups. So, comprehensive analysis of the biochemical parameters will be very helpful for early identification $\&$ better management of severe disease.

Keywords: C-reactive protein; lactate dehydrogenase; Random blood glucose; Serum glutamic-pyruvic-transaminase; STA

\section{Introduction}

Corona virus was first isolated and named in the 1960s which belongs to the family Coronoviridae. It is a zoonotic positive strand RNA envelope virus that can spread between animals and humans. This virus has a spherical or pleomorphic shape with glycoprotein in the viral envelope structure. On February 12, 2020, the World Health Organization (WHO) officially named novel corona virus-2(SARS-Cov-2) and the pneumonia caused by novel coronavirus was named COVID-19. The third fatal corona virus identified is the novel corona virus (SARS-CoV2) that causes novel corona pneumonia (COVID-19) which first broke in Wuhan, China in December 2019 [1]. Currently the COVID-19 pandemic is leading to millions of infections and thousands of deaths worldwide [2,3]. Recently, novel coronavirus infection has affected more than 200 countries and regions around the world. Up to mid May 2020, more than 4 million people have been infected and about 300,000 have died [4]). First case of COVID-19 was detected in Bangladesh on 8th March, 2020 [5].

Coronavirus enters the pulmonary alveolar epithelial cells though angiotensin converting enzyme 2 (ACE2) [2,6]. The main mechanism for inflammation and organ damage is cytokines storm, especially in pulmonary vascular endothelial cells with increased inflammatory cytokines such as interleukins (IL1B, IL-6, IL-12, IL-10), tumour necrosis factor (INF) \& monocyte chemoattractant protein (MCP-1) [7]. This virus initially undergoes viral replication in the respiratory tract and then spread to other organs and tissues $[8,9,10]$.

The presence of circulating viral particles induces the activations of neutrophils and macrophages and leads to synthesis of pro- inflammatory substances such as cytokines. [9]. These inflammation causes changes in the function of several organs, leads to various changes in haematological and biochemical parameters among mild, moderate and severe COVID-19 patients $[11,12]$. At the pulmonary level, viral replication causes hypoxia, cell death and lesions in the capillaries. Thus, it triggers the inflammatory process that causes activation of platelets and induces the formation of microcoagulation, this can become widespread, causing damage to other organs such as the heart, liver and kidneys [8, $11,12]$. These inflammatory and pathological process causes changes in the function of several organs, thus leads to biochemical changes in COVID-19 patients. Most common being hypoalbuminemia, increase in CRP, D-dimer, prothrombin time, LDH, ferritin, SGPT and serum creatinine [13].

\section{Material and methods}

\subsection{Study population and case definition}

The study was conducted on total number of 100 real time- polymerase chain reaction (RT-PCR) positive COVID-19 patients. Subjects were selected from COVID-19 wards of Dhaka Medical College and Hospital. Based on radiological features, respiratory rate and oxygen saturation, study subjects were categorized into mild, moderate and severe COVID-19 cases.

Blood samples were collected from total 100 subjects during different course (mostly in $2^{\text {nd }}$ week) of their illness.

Out of them, 25 mild COVID-19 study subjects were included in group A, 38 moderate COVID19 study subjects were included in group B and 37 severe COVID-19 study subjects were included in group C.

\subsection{Clinical case definition}

\subsubsection{Mild cases}

The clinical symptoms are mild and there is no signs of pneumonia on imaging. Symptoms may be fever, cough, sore throat, malaise, headache, muscle pain without shortness of breath or abnormal chest imaging. 


\subsubsection{Moderate cases}

Fever and respiratory symptoms with radiological findings of pneumonia with respiratory rate with $<30 \mathrm{breaths} / \mathrm{min}$ and oxygen saturation $>93 \%$ at ambient air.

\subsubsection{Severe cases}

Cases meeting any of the following criteria: Respiratory distress (respiratory rate $\geq 30$ breaths / min), oxygen saturation $\leq 93 \%$ at rest, arterial partial pressure of oxygen $\left(\mathrm{PaO}_{2}\right) /$ fraction of inspired oxygen $\left(\mathrm{FiO}_{2}\right)<300 \mathrm{mmHg} \cdot(1 \mathrm{~mm} \mathrm{Hg}=$ $0.133 \mathrm{kPa})[14]$.

\subsection{Sample collection}

With all aseptic precautions, $10 \mathrm{ml}$ of venous blood was collected from ante-cubital vein by $10 \mathrm{cc}$ disposable plastic syringe, from each subject. Then blood samples were sent for biochemical analysis in the Department of Laboratory, Dhaka Medical College Hospital, Dhaka.

\section{Results}

A total of 100 RT-PCR positive COVID-19 patients were included in this study. The age range of the study subjects was from 18 to 65 years. The mean $( \pm$ SD) age of the study subjects in mild, moderate and severe COVID cases were $41.52 \pm$ 13.48 years, $47.32 \pm 12.10$ years and $45.24 \pm 13.97$ years respectively. The $p$ value $(0.451)$ was not statistically significant (Table-1). In study subjects, there were 67 (67\%) males and 33 (33\%) females. No significant difference was found between mild, moderate \& severe group and gender distribution ( $p$ value0.702).

The mean $( \pm S D)$ D-dimer of the study subjects in mild, moderate and severe COVID-19 cases were $0.98 \pm 2.60,1.16 \pm$ 1.06 and $4.78 \pm 3.42 \mu \mathrm{g} / \mathrm{ml}$ respectively. The mean $( \pm \mathrm{SD})$ Prothrombin time of the study subjects in mild, moderate and severe COVID-19 cases were $13.28 \pm 1.10,13.89 \pm 1.84$ and $14.86 \pm 2.68$ seconds respectively. Both D-dimer\& prothrombin time were statistically significant ( $p$ value $<0.001)$.

The mean $( \pm$ SD) serum creatinine of the study subjects in mild, moderate and severe COVID-19 cases were $0.95 \pm 0.20$, $1.04 \pm 0.30$ and $1.45 \pm 1.25 \mathrm{mg} / \mathrm{dl}$ respectively \& statistically significant $(p$ value $<0.001)$.

The mean $( \pm$ SD) RBG of the study subjects in mild, moderate and severe COVID-19 cases were 8.88 $\pm 4.50,10.82 \pm 4.66$ and $11.42 \pm 5.75 \mathrm{mg} / \mathrm{L}$ respectively and but statistically not significant.

Table 1 Demographic profile of mild, moderate \& severe COVID19 patients (N=100)

\begin{tabular}{|c|c|c|c|c|}
\hline & $\begin{array}{l}\text { Mild (Group A) } \\
(n=25)\end{array}$ & $\begin{array}{l}\text { Moderate (Group } \\
\text { B) }(n=38)\end{array}$ & $\begin{array}{l}\text { Severe (Group C) } \\
(n=37)\end{array}$ & $p$ value \\
\hline $\begin{array}{l}\text { Age (years) } \\
\leq 30\end{array}$ & 7 (28.0) & 3 (7.9) & 7 (18.9) & \\
\hline $31-40$ & 7 (28.0) & $11(28.9)$ & $8(21.6)$ & \\
\hline $41-50$ & $3(12.0)$ & 9 (23.7) & $6(16.2)$ & \\
\hline $51-60$ & 7 (28.0) & 9 (23.7) & $12(32.4)$ & \\
\hline$>60$ & $1(4.0)$ & $6(15.8)$ & $4(10.8)$ & \\
\hline $\begin{array}{l}\text { Mean } \pm \text { SD } \\
\text { (Range) }\end{array}$ & $\begin{array}{c}41.52 \pm 13.48 \\
(18-61)\end{array}$ & $\begin{array}{c}47.32 \pm 12.10 \\
(23-65)\end{array}$ & $\begin{array}{c}45.24 \pm 13.97 \\
(18-65)\end{array}$ & $0.236^{\mathrm{a}}$ \\
\hline \multicolumn{5}{|l|}{ Gender } \\
\hline Male & $18(72.0)$ & $26(68.4)$ & $23(62.2)$ & $0.702^{\mathrm{b}}$ \\
\hline Female & 7 (28.0) & $12(31.6)$ & $14(37.8)$ & \\
\hline
\end{tabular}

$\mathrm{N}=$ Total number of subjects., ${ }^{\mathrm{a}}: \mathrm{p}$ value reached from ANOVA test, ${ }^{\mathrm{b}}: \mathrm{p}$ value reached from chi squared test. 
The mean $( \pm$ SD) CRP of the study subjects in mild, moderate and severe COVID-19 cases were 7.40 $\pm 3.58,12.92 \pm 7.96$ and $23.24 \pm 20.81 \mathrm{mg} / \mathrm{L}$ respectively. The mean $( \pm \mathrm{SD}$ ) serum LDH of the study subjects in mild, moderate and severe COVID-19 cases were 281. $46 \pm 150.13,462.95 \pm 236.19$ and $655.70 \pm 223.25 \mathrm{U} / \mathrm{L}$ respectively.

The mean $( \pm$ SD) serum ferritin of the study subjects in mild, moderate and severe COVID-19 cases were $173.62 \pm 98.93$, $386.33 \pm 238.04$ and $1003.36 \pm 555.50 \mathrm{ng} / \mathrm{ml}$ respectively. These findings are statistically significant $(p$ value $<0.001)$.

The mean $( \pm$ SD) SGPT of in mild, moderate and severe COVID-19 cases were $32.04 \pm 19.74,33.74 \pm 15.31$ and $45.32 \pm$ $20.21 \mathrm{U} / \mathrm{L}$ respectively. This finding is statistically significant ( $p$ value 0.007$)$. The mean $( \pm \mathrm{SD})$ serum albumin of the study subjects in mild, moderate and severe COVID-19 cases were $3.42 \pm 0.47,3.26 \pm 0.31$ and $3.18 \pm 0.40 \mathrm{~g} / \mathrm{dl}$ respectively. This finding of is not statistically significant ( $p$ value 0.774 ).

Correlation study of this study shows statistically significant positive correlation of D-dimer, prothrombin time, serum creatinine, CRP, LDH, Ferritin \& SGPT RBG showed positive correlation with the severity of disease. But Serum albumin showed negative correlation with severity of disease.

Table 1 shows no significant difference of severity of COVID-19 in respect of age and gender

Table 2 Biochemical findings of the study subjects $(\mathrm{N}=100)$

\begin{tabular}{|c|c|c|c|c|}
\hline Bio-chemical findings & $\begin{array}{c}\text { Mild } \\
\text { (Group A) } \\
(n=25)\end{array}$ & $\begin{array}{c}\text { Moderate } \\
\text { (Group B) } \\
(n=38)\end{array}$ & $\begin{array}{c}\text { Severe } \\
\text { (Group C) } \\
(n=37)\end{array}$ & $p$-value \\
\hline $\mathrm{RBG}(\mathrm{mmol} / \mathrm{L})$ & $\begin{array}{c}8.88 \pm 4.50 \\
(4.8-20)\end{array}$ & $\begin{array}{c}10.82 \pm 4.66 \\
(5.2-22.5)\end{array}$ & $\begin{array}{c}11.42 \pm 5.75 \\
(4.8-23)\end{array}$ & 0.146 \\
\hline $\mathrm{CRP}(\mathrm{mg} / \mathrm{L})$ & $\begin{array}{c}7.40 \pm 3.58 \\
(<6-18)\end{array}$ & $\begin{array}{c}12.92 \pm 7.96 \\
(<6-40)\end{array}$ & $\begin{array}{c}23.24 \pm 20.81 \\
(8-48)\end{array}$ & $<0.001$ \\
\hline SGPT (U/L) & $\begin{array}{c}32.04 \pm 19.74 \\
(12-101)\end{array}$ & $\begin{array}{c}33.74 \pm 15.31 \\
(15-89)\end{array}$ & $\begin{array}{c}45.32 \pm 20.21 \\
(25-112)\end{array}$ & 0.007 \\
\hline Serum Creatinine (mg/dl) & $\begin{array}{c}0.95 \pm 0.20 \\
(0.46-1.2)\end{array}$ & $\begin{array}{l}1.04 \pm 0.30 \\
(0.52-2.09)\end{array}$ & $\begin{array}{l}1.45 \pm 1.25 \\
(0.55-2.35)\end{array}$ & 0.024 \\
\hline S. LDH (U/L) & $\begin{array}{c}281.46 \pm 150.13 \\
(129-640)\end{array}$ & $\begin{array}{c}462.95 \pm 236.19 \\
(52-1116)\end{array}$ & $\begin{array}{c}655.70 \pm 223.25 \\
(200-1306)\end{array}$ & $<0.001$ \\
\hline $\mathrm{S}$ ferritin $(\mathrm{ng} / \mathrm{ml})$ & $\begin{array}{c}173.62 \pm 98.93 \\
(60-425)\end{array}$ & $\begin{array}{c}386.33 \pm 238.04 \\
(25-1012)\end{array}$ & $\begin{array}{c}1003.36 \pm 555.50 \\
(135-3344)\end{array}$ & $<0.001$ \\
\hline $\mathrm{D}$ dimer $(\mu \mathrm{g} / \mathrm{ml})$ & $\begin{array}{l}0.98 \pm 2.60 \\
(0.11-4.35)\end{array}$ & $\begin{array}{c}1.16 \pm 1.06 \\
(0.10-5.3)\end{array}$ & $\begin{array}{l}4.78 \pm 3.42 \\
(0.87-8.68)\end{array}$ & $<0.001$ \\
\hline $\mathrm{S}$ albumin $(\mathrm{g} / \mathrm{dl})$ & $\begin{array}{c}3.42 \pm 0.47 \\
((2.2-4.5)\end{array}$ & $\begin{array}{c}3.26 \pm 0.31 \\
(2.0-4.2)\end{array}$ & $\begin{array}{c}3.18 \pm 0.40 \\
(1.9-4.1)\end{array}$ & 0.774 \\
\hline Prothrombin time (sec) & $\begin{array}{c}13.28 \pm 1.10 \\
(12-16)\end{array}$ & $\begin{array}{c}13.89 \pm 1.84 \\
(12-20)\end{array}$ & $\begin{array}{c}14.86 \pm 2.68 \\
(12-27)\end{array}$ & 0.011 \\
\hline
\end{tabular}

Table 2 shows severity of the disease was significantly associated with CRP, SGPT, S. Creatinine, LDH, Ferritin, D-dimer \& Prothrombin time. No significant association was found with RBG \& S. Albumin. ANOVA test was done to measure the level of significance.RBG: Random blood Glucose, CRP: C-reactive protein, LDH: Lactate Dehydrogenase 
Table 3 Bonferroni correction for biochemical parameters

\begin{tabular}{|l|c|c|c|}
\hline \multirow{2}{*}{$\begin{array}{l}\text { Biochemical } \\
\text { parameters }\end{array}$} & Mild vs moderate & Moderate vs severe & $\begin{array}{l}\text { Mild } \\
\text { severe }\end{array}$ \\
\cline { 2 - 4 } & & 0.418 & 0.166 \\
\hline RBG & 0.023 & $<0.001$ & $<0.001$ \\
\hline C reactive protein & 1.000 & 0.022 & 0.019 \\
\hline SGPT & 0.700 & 0.002 & $<0.001$ \\
\hline Serum creatinine & 0.008 & $<0.001$ & $<0.001$ \\
\hline S. LDH & 0.086 & $<0.001$ & $<0.001$ \\
\hline D dimer & 1.000 & $<0.001$ & $<0.001$ \\
\hline S. albumin & 1.000 & 1.000 & 1.000 \\
\hline Prothrombin time & 0.750 & 0.133 & 0.011 \\
\hline
\end{tabular}

Bonferroni correction following ANOVA was performed to compare between groups. The test of significance $(p$ value $<0.05)$ was calculated for all the comparisons.

Table 4 Correlation of diseases severity with biochemical parameters

\begin{tabular}{|l|c|c|}
\hline & $\mathrm{r}_{\mathrm{s}}$ & $p$-value \\
\hline RBG & +0.157 & 0.119 \\
\hline C reactive protein & +0.704 & $<0.001$ \\
\hline SGPT & +0.390 & $<0.001$ \\
\hline Serum creatinine & +0.466 & $<0.001$ \\
\hline S. LDH & +0.593 & $<0.001$ \\
\hline S. ferritin & +0.767 & $<0.001$ \\
\hline D dimer & +0.743 & $<0.001$ \\
\hline S. albumin & -0.158 & 0.117 \\
\hline Prothrombin time & +0.307 & 0.002 \\
\hline
\end{tabular}

Spearman's correlation coefficient ( $\mathrm{r}$ ) test was performed to compare relationship between haematological parameters and severity of disease. Finding shows statistically significant $(p$-value $<0.05$ ) positive correlation with CRP, SGPT, S. Creatinine, LDH, Ferritin, D-dimer \& Prothrombin time.

\section{Discussion}

The present study was undertaken to assess the findings of biochemical parameters of mild, moderate and severe COVID-19 patients. For this purpose, a total number of 100 RT-PCR positive COVID-19 patients with age ranging from 18 to 65 years were included in this study on the basis of inclusion and exclusion criteria. In this study, the number of mild, moderate and severe COVID-19 cases were 25, 38 and 37 respectively.

In the study, pulse, blood pressure and temperature were measured to assess the general condition of the patients. Based on radiological features, respiratory rate and oxygen saturation, study subjects were categorized into mild, moderate and severe COVID-19 cases.

Pathogenesis of COVD-19 may be associated with a high cytokine level. Severe COVID-19 infection is typically characterised by a massive, pro-inflammatory response, or cytokine storm, triggered by the immune system that results in acute respiratory distress syndrome (ARDS) and multi organ dysfunctions $[15,16,17,1819]$. 
The mean $( \pm$ SD) D-dimer of the study subjects in mild, moderate and severe COVID-19 cases were statistically significant ( $p$ value $<0.001$ ). Similar types of observations were found by some researchers [5, 20,21,22]. D-dimer is a specific and sensitive marker of coagulation and fibrinolysis activation, as well as being crucial to the diagnosis of disseminated intravascular coagulation (DIC) [23].

Patients with viral infection as well as COVID-19 are at higher risk of developing these complications [24,25].

Regarding coagulopathies, increased D-dimer and increased prothrombin time can be observed, which can be seen in $40 \%$ patients with COVID-19. These would be associated with influence of the virus and cytokines in the bone marrow $[26,27]$. High D-dimer concentration may result from the inflammation associated with COVID-19 and subsequent activation of coagulation system [28]. Elevated D-dimer level suggests a hypercoagulable state and may be contributing to severity of illness and mortality [11].

The mean $( \pm S D)$ Prothrombin time of the study subjects in mild, moderate and severe COVID-19 cases were significant ( $p$ value $<0.011$ ). Similar finding was found by [22].

The inflammatory and pathological process causes changes in the function of several organs. When these inflammations involved kidney, it causes injury to kidney. So serum creatinine is one of the parameters for the analysis of kidney injuries induced by COVID-19 [29]. Due to higher accumulation of ACE-2 receptors in renal tubules, kidney is able to express this enzyme more than 100 times as much as the lungs [30,31,32]. The mean $( \pm S D)$ serum creatinine of the study subjects in mild, moderate and severe COVID-19 cases were statistically significant ( $p$ value 0.024 ). This finding was in agreement with the study done by [31] whereas [33] found no association of S. Creatinine with the severity of COVID-19.

In the present study, RBG was also done to see the glycemic status of the study subjects. RBG of the study subject ranges from 4.8 to $23 \mathrm{mmol} / \mathrm{L}$. Frequency of Diabetes Mellitus (DM) was found to be $40 \%$. The mean $( \pm \mathrm{SD}) \mathrm{RBG}$ of the study subjects in mild, moderate and severe COVID-19 cases were not statistically significant. On the contrary, some studies shows that DM is a risk factor and contributes to the severity and mortality of patients with COVID-19 [34, 35, 36].

CRP, a routinely measured inflammatory marker, is increased in most patients with COVID-19 and associated with disease severity [17,37,38]. [38] evaluated 85 patients diagnosed with COVID-19, of which $96.47 \%$ showed an increase in CRP, being influenced by the severity level of the pathology. As one of most distinctive acute phase reactants, CRP can increase rapidly after onset of inflammation, cell damage or tissue injury. Pulmonary diseases with inflammatory features usually raise serum CRP level in response to several inflammatory cytokine such as IL-6, IL-1 or TNF. Hence, markedly elevated serum CRP level in severe illness indicates excessive inflammatory response, which is consistent with raised serum pro-inflammatory cytokines observed in COVID-19 patients [7, 39].

Ferritin, the major intracellular iron storage protein, is an acute phase reactant. Ferritin is elevated in many inflammatory conditions, including acute infections [40]. Elevated ferritin levels due to secondary haemophagocytic lymphocytosis and cytokine storm syndrome have been reported in patients with severe COVID-19 [41].

LDH is found in all cells, especially in myocardial and liver cells. Raised LDH is an indicator of multi-organ injury (Huang C., et al., 2020). Study showed that increase in LDH level was associated with poor outcome [42].

The mean $( \pm S D)$ CRP, LDH \& serum ferritin of the study subjects in mild, moderate and severe COVID-19 cases were statistically significant ( $p$ value $<0.001$ ). Similar significant finding was found by some researchers of different countries $[5,43,44]$.

Viral activity induces several inflammatory changes that can lead to liver tissue damage, increased levels of liver enzymes specially SGPT [45]. In most cases, the liver injury was transient and in mild form. However, severe liver dysfunction has been reported in patients with severe COVID-19 [45]. In a Chinese study very high SGPT (more than $7500 \mathrm{U} / \mathrm{L}$ ) has been reported [46]. It is not clear whether the observed SARS- CoV-2 associated liver injury is caused by direct viral injury or related to hepatotoxic drugs, coexisting systemic inflammatory changes, sepsis, respiratory distress syndrome induced hypoxia or a part of multiple organ failure [47]. COVID-19 induced cytokine storm can causes hepatotoxicity and subsequently critical hypoalbuminemia [48].

The mean $( \pm$ SD) SGPT of in mild, moderate and severe COVID-19 cases were statistically significant ( $p$ value 0.007$)$. The mean $( \pm$ SD) serum albumin of the study subjects in mild, moderate and severe COVID-19 cases were not statistically 
significant. [45] identified that patients with severe manifestation of COID-19 exhibited higher level of SGPT but lower serum albumin.

Furthermore, in the present study, CRP, SGPT, serum creatinine, LDH, serum ferritin, D-dimer showed positive correlations. But serum albumin showed negative correlation with severity of disease. These correlations further strengthen the findings of the present study.

This present study had some limitations. Samples were taken purposively so that there may be chance of bias which can influence the results. Blood samples were not taken in specific time of course of illness of study subjects. More investigations like serum procalcitonin, serum lipase, Troponin I, Interleukin-6, Immunoglobulins could not be done due to financial constraints, time and lack of availability.

\section{Conclusion}

Several biochemical parameters have significant association with the severity of COVID19 infection as shown in this study. So, routine screening of these biochemical parameters will be very much helpful for better management and identification the complications and to reduce the overall mortality and morbidity.

\section{Compliance with ethical standards}

\section{Acknowledgments}

The authors acknowledge the patients of COVID-19 unit, Dhaka Medical College Hospital for their cooperation.

\section{Disclosure of conflict of interest}

The author declares no conflict of interest.

\section{Statement of ethical approval}

Ethical clearance of this study was obtained from concerned Departments, Research review committee and Ethical review committee of Dhaka Medical College, Dhaka.

\section{Statement of informed consent}

Informed consent was obtained from all individual participants included in this study.

\section{References}

[1] Zhu N, Zhang D, Wang W, Li X, Yang B, Song J, Zhao X, Huang B, Shi W, Lu R, Niu P. (2020). A novel coronavirus from patients with pneumonia in China, 2019. New England journal of medicine, 382, 727-733.

[2] Jiang F, Deng L, Zhang L, Cai Y, Cheung CW, Xia Z. (2020). Review of the clinical characteristics of coronavirus disease 2019 (COVID-19). (2020). Journal of general internal medicine, 35(5), 1545-1549.

[3] Peeri NC, Shrestha N, Rahman MS, Zaki R, Tan Z, Bibi S, Baghbanzadeh M, Aghamohammadi N, Zhang W, Haque U. (2020). The SARS, MERS and novel coronavirus (COVID-19) epidemics, the newest and biggest global health threats: what lessons have we learned?.International journal of epidemiology, 49(3): 717-726.

[4] Yuan X, Huang W, Ye B, Chen C, Huang R, Wu F, Wei Q, Zhang W, Hu J. (2020). Changes of hematological and immunological parameters in COVID-19 patients. International journal of hematology, 112(4): 553-559.

[5] Bhuiyan MN, Giti S, Hossen MS, Rahman MM, Zannat MN, Chokroborty S. (2020). Haematologic Profile Abnormalities and Coagulopathy Associated with Covid-19: A Prospective Study of 100 Patients. Journal of Bangladesh College of Physicians and Surgeons, 3, 61-66.

[6] Wan S, Xiang YI, Fang W, Zheng Y, Li B, Hu Y, Lang C, Huang D, Sun Q, Xiong Y, Huang X. (2020). Clinical features and treatment of COVID-19 patients in northeast Chongqing. Journal of medical virology, 92(7), 797-806.

[7] Huang C, Wang Y, Li X, Ren L, Zhao J, Hu Y, Zhang L, Fan G, Xu J, Gu X, Cheng Z. (2020). Clinical features of patients infected with 2019 novel coronavirus in Wuhan, China. The lancet, 395(10223). 497-506. 
[8] Xu P, Zhou Q, Xu J. (2020). Mechanism of thrombocytopenia in COVID-19 patients. Annals of hematology, 99(6), 1205-1208.

[9] Cascella M, Rajnik M, Aleem A, Dulebohn S, Di Napoli R. (2021). Features, evaluation, and treatment of coronavirus (COVID-19). StatPearls, 52(171), 1-7.

[10] Amgalan A, Othman M. (2020). Exploring possible mechanisms for COVID-19 induced thrombocytopenia: Unanswered questions. Journal of Thrombosis and Haemostasis, 18(6), 1514-1516.

[11] Lippi G, Plebani M. (2020). Laboratory abnormalities in patients with COVID-2019 infection. Clinical Chemistry and Laboratory Medicine (CCLM), 58(7), 1131-1134

[12] Sardu C, Gambardella J, Morelli MB, Wang X, Marfella R, Santulli G. (2020). Hypertension, thrombosis, kidney failure, and diabetes: is COVID-19 an endothelial disease? A comprehensive evaluation of clinical and basic evidence. Journal of clinical medicine, 9(5), 14-17.

[13] Kramer DG, de Sousa AM. (2020). Endothelial Dysfunction in Coronavirus disease: A Literature Review: Endothelial Dysfunction in Coronavirus disease. Journal of Health Science Research, 27-31.

[14] Who.int. 2020. [online]

[15] Lu R, Zhao X, Li J, Niu P, Yang B, Wu H, Wang W, Song H, Huang B, Zhu N, Bi Y. (2020). Genomic characterisation and epidemiology of 2019 novel coronavirus: implications for virus origins and receptor binding. The lancet, 395(10224), 565-574.

[16] Yan R, Zhang Y, Li Y, Xia L, Guo Y, Zhou Q. (2020). Structural basis for the recognition of SARS-CoV-2 by full-length human ACE2. Science, 367(6485), 1444-1448.

[17] Qin C, Zhou L, Hu Z, Zhang S, Yang S, Tao Y, Xie C, Ma K, Shang K, Wang W, Tian DS. (2020). Dysregulation of immune response in patients with coronavirus 2019 (COVID-19) in Wuhan, China. Clinical infectious diseases, 71(15), 762-768.

[18] Rivière S, Galicier L, Coppo P, Marzac C, Aumont C, Lambotte O, Fardet L. (2014). Reactive hemophagocytic syndrome in adults: a retrospective analysis of 162 patients. The American journal of medicine, 127(11), 11181125.

[19] Ramos-Casals M, Brito-Zerón P, López-Guillermo A, Khamashta MA, Bosch X. (2014). Adult haemophagocytic syndrome. The Lancet., 383(9927), 1503-1516.

[20] Yao Y, Cao J, Wang Q, Shi Q, Liu K, Luo Z, Chen X, Chen S, Yu K, Huang Z, Hu B. (2020). D-dimer as a biomarker for disease severity and mortality in COVID-19 patients: a case control study. Journal of intensive care, 8(1), 1-11.

[21] Konukoglu D. (2020). COVID-19: Clinical and pathophysiological features and laboratory diagnosis. International Journal of Medical Biochemistry, 3(2), 47-51.

[22] Velavan TP, Meyer CG. (2020). Mild versus severe COVID-19: laboratory markers. International Journal of Infectious Diseases, 95, 304- 307.

[23] Favresse J, Lippi G, Roy PM, Chatelain B, Jacqmin H, Ten Cate H, Mullier F. (2018). D-dimer: Preanalytical, analytical, postanalytical variables, and clinical applications. Critical reviews in clinical laboratory sciences, 55(8), 548- 577.

[24] Long H, Nie L, Xiang X, Li H, Zhang X, Fu X, Ren H, Liu W, Wang Q, Wu Q. (2020). D-dimer and prothrombin time are the significant indicators of severe COVID-19 and poor prognosis. BioMed research international, 1- 10.

[25] Goeijenbier M, Van Wissen M, Van De Weg C, Jong E, Gerdes VE, Meijers JC, Brandjes DP, Van Gorp EC. (2012). Viral infections and mechanisms of thrombosis and bleeding. Journal of medical virology, 84(10), 1680- 1896.

[26] Rotzinger DC, Beigelman-Aubry C, Von Garnier C, Qanadli S. (2020). Pulmonary embolism in patients with COVID19: time to change the paradigm of computed tomography. Thrombosis research, 190, 58- 69.

[27] Ekinci O, Candar O, Dogan A, Esen R, Demir C. (2018). Disseminated Intravascular Coagulation: A Single Center Experience. Eastern Journal of Medicine, 23(1), 31.

[28] Connors JM, Levy JH. (2020). COVID-19 and its implications for thrombosis and anticoagulation. Blood, 135(23), 2033-2040.

[29] Guan WJ, Ni ZY, Hu Y, Liang WH, Ou CQ, He JX, Liu L, Shan H, Lei CL, Hui DS, Du B. (2020). Clinical characteristics of coronavirus disease 2019 in China. New England journal of medicine, 382(18), 1708-1720. 
[30] Huang Y, Tu M, Wang S, Chen S, Zhou W, Chen D, Zhou L, Wang M, Zhao Y, Zeng W, Huang Q. (2020). Clinical characteristics of laboratory confirmed positive cases of SARS-CoV-2 infection in Wuhan, China: A retrospective single center analysis. Travel medicine and infectious disease, 31(7), 894-901.

[31] Wang L, Wang Y, Ye D, Liu Q. (2020). Review of the 2019 novel coronavirus (SARS-CoV-2) based on current evidence. International journal of antimicrobial agents, 55(6), 105948.

[32] Guo L, Yu K, Li D, Yang H, Liu L, Fan J, Sun N, Yang X. (2020). Potential pathogenesis of multiple organ injury in COVID-19. 1-11.

[33] Li Q, Cao Y, Chen L, Wu D, Yu J, Wang H, He W, Chen L, Dong F, Chen W, Chen W. (2020). Hematological features of persons with COVID-19. Leukemia, 34(8), 2163- 2172.

[34] Abdi A, Jalilian M, Sarbarzeh PA, Vlaisavljevic Z. (2020). Diabetes and COVID-19: A systematic review on the current evidences. diabetes research and clinical practice, 166, 108347.

[35] Shang J, Wang Q, Zhang H, Wang X, Wan J, Yan Y, Gao Y, Cheng J, Li Z, Lin J. (2021). The relationship between diabetes mellitus and COVID-19 prognosis: a retrospective cohort study in Wuhan, China. The American journal of medicine, 134(1), 6-14.

[36] Yaribeygi H, Sathyapalan T, Jamialahmadi T, Sahebkar A. (2020). The Impact of Diabetes Mellitus in COVID-19: A Mechanistic Review of Molecular Interactions. Journal of Diabetes Research, 1-9.

[37] Zhang JJ, Dong X, Cao YY, Yuan YD, Yang YB, Yan YQ, Akdis CA, Gao YD. (2020). Clinical characteristics of 140 patients infected with SARS-CoV-2 in Wuhan, China. Allergy, 75(7), 1730-1741.

[38] Yang W, Cao Q, Qin LE, Wang X, Cheng Z, Pan A, Dai J, Sun Q, Zhao F, Qu J, Yan F. (2020). Clinical characteristics and imaging manifestations of the 2019 novel coronavirus disease (COVID-19): a multi-center study in Wenzhou city, Zhejiang, China. Journal of Infection, 80(4), 388-393.

[39] Liu Y, Yang Y, Zhang C, Huang F, Wang F, Yuan J, Wang Z, Li J, Li J, Feng C, Zhang Z. (2020). Clinical and biochemical indexes from 2019-nCoV infected patients linked to viral loads and lung injury. Science China Life Sciences, 63(3), 364-374.

[40] Kernan KF, Carcillo JA. (2017). Hyperferritinemia and inflammation. International immunology, 29(9): $401-409$.

[41] Mehta P, McAuley DF, Brown M, Sanchez E, Tattersall RS, Manson JJ. (2020). COVID-19: consider cytokine storm syndromes and immunosuppression. The lancet, 395(10229), 1033-1034.

[42] Dick J, Lang N, Slynko A, Kopp-Schneider A, Schulz C, Dimitrakopoulou-Strauss A, Enk AH, Hassel JC. (2020). Use of LDH and autoimmune side effects to predict response to ipilimumab treatment. Immunotherapy, 8(9), 10331044.

[43] Chen W, Zheng KI, Liu S, Yan Z, Xu C, Qiao Z. (2020). Plasma CRP level is positively associated with the severity of COVID-19. Annals of clinical microbiology and antimicrobials, 19, 1-7.

[44] Yuan X, Huang W, Ye B, Chen C, Huang R, Wu F, Wei Q, Zhang W, Hu J. (2020). Changes of hematological and immunological parameters in COVID-19 patients. International journal of hematology, 112(4), 553-559.

[45] Youssef M, H Hussein M, Attia AS, M Elshazli R, Omar M, Zora G, S Farhoud A, Elnahla A, Shihabi A, Toraih EA, S Fawzy M. (2020). COVID-19 and liver dysfunction: a systematic review and meta-analysis of retrospective studies. Journal of medical virology, 92(10), 1825-33.

[46] Zhao D, Yao F, Wang L, Zheng L, Gao Y, Ye J, Guo F, Zhao H, Gao R. (2020). A comparative study on the clinical features of coronavirus 2019 (COVID-19) pneumonia with other pneumonias. Clinical Infectious Diseases, 71(15), 756-761.

[47] Chen N, Zhou M, Dong X, Qu J, Gong F, Han Y, Qiu Y, Wang J, Liu Y, Wei Y, Yu T. (2020). Epidemiological and clinical characteristics of 99 cases of 2019 novel coronavirus pneumonia in Wuhan, China: a descriptive study. The Lancet, 395(10223), 507-513.

[48] Feng G, Zheng KI, Yan QQ, Rios RS, Targher G, Byrne CD, Van Poucke S, Liu WY, Zheng MH. (2020). COVID-19 and liver dysfunction: current insights and emergent therapeutic strategies. Journal of clinical and translational hepatology, 8(1), 18. 